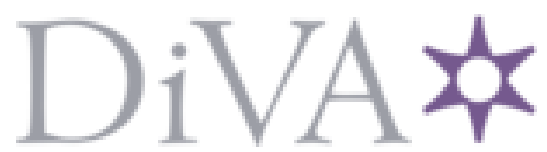

http://www.diva-portal.org

\title{
Postprint
}

This is the accepted version of a paper published in Intercultural Education. This paper has been peer-reviewed but does not include the final publisher proof-corrections or journal pagination.

Citation for the original published paper (version of record):

Rosvall, P-Å. (2017)

Understanding career development amongst immigrant youth in a rural place

Intercultural Education, 28(6): 523-542

https://doi.org/10.108o/14675986.2017.1392680

Access to the published version may require subscription.

N.B. When citing this work, cite the original published paper.

Permanent link to this version:

http://urn.kb.se/resolve?urn=urn:nbn:se:umu:diva-141571 


\section{Understanding career development amongst immigrant youth in a rural place}

Publication information: Rosvall, P.-Å. (2017). Understanding career development amongst immigrant youth in a rural place. Intercultural Education, 28(6), 523-542.

doi:10.1080/14675986.2017.1392680

\section{Per-Åke Rosvall}

Department of Applied Educational Science, Umeå University, Umeå, Sweden

Corresponding author: Per-Åke Rosvall

E-mail: per-ake.rosvall@umu.se

Postal address: Per-Åke Rosvall, Umeå University, Department of Applied Educational Science, SE-901 87 Umeå, Sweden.

Phone: +46907865600

Fax: NA

Funding: This work was supported by the Swedish Research Council [grant number 2013-2142].

Per-Åke Rosvall is an associate professor with particular interest in the sociology of education at Umeå University, Sweden. Rosvall is a member of the Nordic centre of excellence, Justice through education in the Nordic countries (JustEd). 


\title{
Understanding career development amongst immigrant youth in a rural place
}

\author{
There is little research into the career trajectories and occupational aspirations of \\ rural youth with immigrant backgrounds in Europe. This article presents new \\ research based on field observations and interviews with five young immigrants \\ of Persian descent in one rural town in Sweden. The findings highlighted gender \\ differences in how the research participants felt their immigrant background \\ would shape their future career plans and aspirations. The boys anticipated that \\ by staying in the local town they may experience less of the stigma that they \\ knew immigrants in urban areas often face. In contrast the girls did not think of \\ their rural home town as the best place to establish a career. One of the girls also \\ spoke of an ambition to divide her working life between her new homeland and \\ her family's country of origin. The analysis stresses the importance of an \\ intercultural understanding of both the local and the global when counselling \\ immigrant youth in rural areas regarding their career choices.
}

Keywords: immigrants; gender issues; rural youth; career development; access; vulnerable groups

\section{Introduction}

Until a century ago there was more migration within or outwards from Europe than into Europe. More recently, as well documented in the media, there has been a strong surge of migration into Europe. In 2015, for example, 76.1 million international migrants were living in Europe, 389000 children applied for asylum in 32 European countries, and 2.8 million people in total sought refuge or asylum in these countries (UN 2016). Recipients of the largest numbers of refugees and asylum seekers were Germany (700 000) followed by Sweden, France and Russian Federation (300 000 each) (UN 2016). Much of this migration can be characterised as having a 'push-dynamic': that is, it is driven by flight from poverty, war, political instability, persecution on religious or ethnic grounds and associated threats such as torture and starvation. For example, nearly 
70 percent of children seeking asylum in Europe in the first half of 2016 were fleeing conflict in the Syrian Arab Republic, Afghanistan or Iraq (UN 2016).

This pattern sharply contrasts with earlier post-WW2 migrations, which were underpinned by a 'pull-dynamic', particularly the movement of labour from areas of high unemployment to areas with high demand for labour. For example, during the period 1955-1969 half a million people migrated to Sweden, mostly from Finland and the eastern Mediterranean countries, and almost all labour immigrants. This shifted in the early 1980s due to the civil wars in Ethiopia and Lebanon, and political oppression in Iran and Chile. The number of refugees and asylum seekers arriving in Sweden has varied due to conflicts, with peaks during the war in the former Yugoslavia in the 1990s and the wars following the attack on the Twin Towers of the World Trade Center in New York on September 11, 2001.

As refugee and asylum immigration did not take off until the 1980s, and there is a longer history of labour immigration, in 2014 Finland was still the most common country of birth for Swedish citizens born outside Sweden, followed by Iraq, Poland and Iran (respectively accounting for 9.9, 8.1, 5.1 and 4.3 percent of the foreign born) (Statistics Sweden 2016a). However, since 2000 more than half of the immigrants received by Sweden have been refugees and asylum seekers born outside Europe (Statistics Sweden 2016b). In Sweden, until the mid-1980s immigrants had generally established in (or in suburbs of) one of Sweden's three largest cities: Stockholm, Gothenburg or Malmö. As a political reaction to the increasing numbers of immigrants fleeing from civil wars in Ethiopia and Lebanon, or political oppression in Iran and Chile, a reform was implemented to distribute immigrants more evenly in the country. Consequently, during the war in the former Yugoslavia (1990-1994) more than 80 percent of refugees were registered in municipalities outside regions of those three 
cities. This trend has continued. Less densely populated municipalities have received more refugees per capita than regions of the large cities, although restrictions introduced by the reform implemented in the mid-1980s were loosened in 2010 . One in eight immigrants assigned to relatively sparsely populated municipalities during the period 2006-2010 were still in the assigned region five years later, compared to three out of four of immigrants assigned to the larger city regions (Swedish Statistics 2016c).

Labour market conditions today are rather different, with both more widespread unemployment and higher demands on workers to have academic qualifications and language skills to secure long-term employment (Nilsson 2004). This has affected where any remaining 'pull-migrants' go, as they gravitate towards distinct locations that offer the best work opportunities. Meanwhile 'push-migrants', who are relocated by national Migration Boards, are spread more diffusely across host countries, with some living in remote areas well away from major urban centres and accessible opportunities for employment. In Sweden, for example, push-migrants are known to have settled in remote regions where they sometimes remain for many years (Statistics Sweden 2008). The same is true of various other European countries (Collantes et al. 2014; MaizteguiOñate and Santibáñez-Gruber 2008).

As part of a project entitled 'Rural Youth: education, place and participation' we have begun to analyse these issues as they have emerged during classroom observations with push-migrants and their children. The wider project's remit is to explore differences in students' participation in rural schools and what students envisage about their opportunities to work and influence their society, now and in the future. This article, though, hones in on a narrower question: what do newly arrived immigrants living in rural areas of Sweden consider to be important factors in their career development? Our analysis considers issues around gender and place, and draws on the 
narratives presented by a small number of newly arrived immigrants. This study may offer important insights for career counselling and guidance with such populations. In the context of continued growth in levels of migration into countries such as Sweden and Germany such insight is urgently needed. For instance, today one in five children in Sweden are of foreign origin, defined as either being born outside Sweden or having two parents born abroad (Statistics Sweden 2016a).

\section{Theory}

This study takes an intercultural approach to analysing career guidance in a context of concerns about the social mobility of marginalised youth (Coulby 2006; Gorski 2008; Perry and Southwell 2011). An intercultural approach here means recognition that cultural awareness per se may not be sufficient to identify some important factors, that the wider socio-political context must be considered, and that monoculturalism may be meaningfully contested. In line with Coulby (2006), who emphasises the importance of context, we also draw on further theoretical contributions that consider place (Massey 1994). Across this body of literature there is a shared view that the characteristics of society are not fixed but rather constantly remade through social interaction and therefore subject to change. As these perspectives are concerned with the relationships between local and global regimes they are useful for analysing local perspectives in wider contexts, thus helping us explore young migrants' understandings of place in relation to their future career development. Connell (1987), in line with Massey (1994), identifies three characteristics that are useful in analysing career development: employment, power and personal relationships. These are seen as features of a local area that need to be conceptualised in light of the evolution of the wider structures of capitalist economies. The identity of a place does not derive from some internalised history. It derives, in large part, precisely from the specificity of its interactions with 
'the outside' (Massey 1994, 169; see also Coulby 2006, 247).

\section{Material and methods}

The wider project in which this study is embedded - 'Rural Youth: education, place and participation' - employs an ethnographic approach incorporating classroom observations and interviews (Jeffrey and Troman, 2004; Rosvall 2015). This study focuses on interviews with, and classroom interactions with peers of, newly arrived migrants and can be seen as a small-scale study within the larger project. As various contributions to this and other journals demonstrate (Borghetti, Beaven and Pugliese 2015; Unjore 2014), small-scale studies offer good opportunities to deepen analysis and understanding of the career choices of under-studied groups of people. This study builds on previous enquiries into the vocational perspectives of immigrants and the interplay of citizenship and career in shaping their choices (Bimrose and McNair 2011; Cohen, Arnold and O'Neill, 2011; Pollak 2008) by taking a more qualitative approach.

The research took place in River Town (not the real name), a town in northern Sweden which grew around a military base that has recently closed, leading to a decline in the town's population. In 2015 the town had just below 9000 inhabitants: this is relatively large for a rural town in Sweden but River Town is still commonly classified as rural due to its remoteness, low population density and relative lack of productive or tourist industries (Swedish Association of Local Authorities and Regions, 2010). It can

further be understood as rural - in both material and imagined ways (Cloke 2006; Massey 1994) - because it displays characteristics typical of rural areas: closeness to nature, remoteness from higher education and some social services (for example, career guidance, paramedic services, healthcare specialists and legal systems), high unemployment poor infrastructure and depopulation. 
Following 25 days of classroom observation during a spring term of a 9th grade class (students ranging from 14-16 years old) all students were invited to be interviewed, both those born in Sweden and those who had recently immigrated. The observations both provided issues to explore in the interviews and enabled a form of data triangulation (Walford 2008). This article specifically focuses on the immigrants who accepted the invitation: two boys and three girls. All of them were 15 years old and had Persian dialects as their mother tongue. All of them were push migrants and asylum seekers. During the period 2011-2015, when they were registered by Swedish authorities, about 104000 immigrants were registered in total, of whom about 16000 were from Afghanistan or Iran (Statistics Sweden 2016c). Their real names are concealed here to maintain their anonymity, and they are referred to pseudonymously as Reza, Rostam, Roshini, Roya and Roshanek.

The interviews were semi-structured and lasted between 35-50 minutes. Roshanek was interviewed individually and the others in pairs. All the interviews were recorded and transcribed prior to analysis. The interviewees' comments and field notes were analysed according to information about career choices and analysed for insights into intercultural understanding (Coulby 2006; Gorski 2008; Perry and Southwell 2011), gender order (Connell 1987), and understanding of place (Massey 1994). Rather than coding the interview transcripts and field notes they were subjected to iterative cycles of reading, interpretation and formulation of theory, as described by Walford $(2008,13)$. To meet the aim of elucidating the factors that newly arrived immigrants living in rural areas of Sweden consider to be important in their career development, this article mainly reports on the interviews with the five immigrants. However, field note observations and the interviews with the students of Swedish origin are used to support 
the interview data and raise questions about discrepancies, as a form of method and source triangulation (Denzin 1989).

The small sample has, we argue, validity in praxis (Cho and Trent 2006). That is, it is justified by the need to redefine the status quo by generating new knowledge about under-studied research participants, while recognising that the emerging claims may be subject to later revision in the light of new evidence. There is very little existing evidence about the career choices of immigrants living in rural areas, although understanding such choices has potentially important implications for career guidance practice. Whilst the findings will not be directly generalisable, one benefit of small samples is the ability to scrutinise how career development plays out in the lives of a group of people without disregarding the research participants' individuality and differences (Blumer 1956).

\section{Results and discussion}

Because the production and analysis of data are intertwined processes in critical ethnography, in this section we present the results and discussion simultaneously, using excerpts from the interviews to illustrate the emerging points. For clarity, the discussion is loosely organised under a series of headings which reflect our interest in the themes of gender and place, although the issues are somewhat overlapping.

\section{Career choices and gender}

In this section, we utilize the concept of 'gender order', defined by (Connell 1987) as 'a historically constructed pattern of power relations between men and women and definitions of femininity and masculinity' (p. 98). In the existing gender order men are generally seen as the norm, which confers certain advantages. Since the gender order is historically constructed it is rather stable, but also constantly changes. It concerns not 
only hierarchical relations between men and women but also those between different groups of men and different groups of women. In other words, there is not only one masculinity or one femininity, they exist in multiple forms (Connell 1987; see also Holm 2010).

In Sweden, as in several other countries (Doolan, Lukić and Buković 2016; Nylund and Rosvall, 2016), there is a clear distinction between vocational and university-oriented education programmes, which students choose depending on the field of employment they are aiming to reach. The transition from compulsory to upper secondary education is the key point in Sweden when students can first choose to take programmes with different curriculums, some vocational and others academic.

Traditionally vocational programmes attract more boys than girls, particularly amongst youth in rural areas. In River Town about 40 percent of students over a five-year period (2009-2014) moved on to vocational programmes after compulsory education, while the overall proportion for all Swedish youth is less than 30 percent (unpublished statistics retrieved from the Swedish National Agency for Education). In other words, following the overall statistics for Rural Town at least two of the five interviewed participants should have had vocational education ambitions, and most likely the boys. However, none of the students we interviewed were considering vocational programmes. All of them were considering academic programmes, which are normally followed by university studies. University studies were also included in the interviewees' plans. However, there were distinct gender differences regarding their future careers and choice of upper secondary programme. Both of the boys said that they intended to apply for the Social Science programme:

Interviewer: What do you think about the future? Which upper secondary programme will you choose?

Reza: I have chosen the Social science programme. Rostam has too. 
Interviewer: Here in River Town?

Rostam: Yes, here!

The Social Science programme is widely seen as one that leaves many career choices open and is the largest programme in Swedish upper secondary schools (Lundahl 2011). Neither of the boys had a clear view of what their future occupation would be, although they had some broad plans which are discussed later in the paper.

In contrast, the girls wanted to attend the Natural Science programme and become physicians:

Interviewer: Which upper secondary programme will you choose?

Roshini: The Natural science programme.

Interviewer: Natural science, yes you told me you wanted to be a doctor! You want to be a doctor specialising in children?

Roshini: Yes!

Interviewer: And what will you do in the autumn?

Roya: I will do grade nine once again since I only came to Sweden recently and my grades are not good enough to get me in to upper secondary education, especially in Swedish and English.

Interviewer: You hope that you will achieve the grades for upper secondary school in a year?

Roya: Yes!

Interviewer: Which upper secondary school programme are you thinking of?

Roya: Natural science.

Interviewer: What work do you want to do later on?

Roya: Surgeon.

The third girl, Roshanek, also wanted to be a physician specialising in paediatric medicine. The Natural Science programme in Sweden is often described as the most prestigious option as it can lead to high-wage and high status jobs such as becoming a physician. However, its prestige is not directly reflected in levels of attendance or the admissions grades required because it is also seen as difficult (Hjelmér and Rosvall 
2016) and therefore lies outside many young individuals' horizon of action (cf.

Hodkinson and Sparkes 1997). In other words, as long as the girls achieve adequate grades in all subjects in their compulsory education they are very likely to be enrolled onto the Natural Science programme. If they do, this may then give them access to university studies and training as a physician.

A recurrent theme in the interviews was the students' high ambitions and the importance of getting respectable positions. This is in line with earlier research (for example studies by Lindgren (2010) and Rao and Hossains (2012), showing that immigrants have high aspirations despite being in disadvantaged positions or locations.

Although in this study both the boys and the girls talked about the importance of having successful careers there were some qualitative differences. The boys talked about the importance of earning enough to support, or at least not be a burden on, their family:

Reza: I want to work as something, and if I do not succeed in achieving it - if I fail - I cannot continue being a burden on my mum. I cannot do that when I am grown up. No, I know what I will do. I will work this summer so I do not have to take study loans. Then I will study and get work. I will be wealthy. I am quite sure about that.

This observation fits existing concepts of gender order (Connell 1987), which see men as being socialised into taking economic care of the family. In other words, the discourse about being successful is closely connected to ideas about care that specifically relate to taking economic responsibility for the family. The girls' thoughts about successful careers were also connected to notions of care, but rather than focusing on supporting their own family they talked of aspirations linked to 'giving back' and participating in the health and social care of vulnerable people, particularly in or connected to their former home lands: 
I asked Roshanek about her future plans. She said that she had seen a lot of suffering and had a special concern about children being exposed to those [kinds of] circumstances. Therefore, she wanted to give care to children as a physician. (Field note, River school)

Health and social care as a profession has historically been associated more with women and what is traditionally seen as the female character. Both in the past and now women are over-represented in occupations such as assistant nurse. However, positions as physicians or doctors have been associated more with men. As recently as 1995 the ratio of female to male physicians in Sweden was 1:2, but following rapid recent changes 45 percent of physicians were female by 2013 (The National Board of Health and Welfare 2013). To some extent, then, these girls' aspirations can be seen as traditional insofar as they relate to the health and care sector, but untraditional in that they aspire to be doctors. At the same time their intended break with the previous gender order reflects wider shifts in the medical profession, as a historically maledominated occupation is quickly becoming more gender-equal. Their aspirations for university studies are consistent with those of other immigrants, who are highly represented in programmes that provide entry to occupations in the public sector, especially healthcare. For example, 77 percent of students enrolled in the pharmacist programme during the school year 2014/2015 were born abroad or had two parents born abroad (Statistics Sweden 2016d). However, the pharmacist programme is relatively small and more individuals with this immigrant background choose the physician programme (the $10^{\text {th }}$ most common choice for students with this background), accounting for 20 percent of the total number who enrol on the programme (Statistics Sweden 2016d). The girls' aspirations are not consistent with most of the cohort at their school, since most of the girls choose vocational programmes that are not oriented 
towards university studies, for example the Child and recreation programme and the Health and social care programme.

\section{Immigrant background and career choice}

Illustrating the idea that individuals' habitus influences the horizon of actions and dreams regarding their career choices (Hodkingson and Sparks 1997) it became obvious that our interviewees' immigrant backgrounds were reflected in their perceptions of their career choices. That is, their experience as immigrants was an important part of their habitus. However, the boys and the girls took this into account in very different ways. For example, the boys talked about their lack of Swedish language skills as a limitation in their career choices:

Reza: I talked with my mom about my career choice. Err, but she said that I could choose whatever I want. But on the other hand she said that I should choose something that is manageable. I do not think that I could be a lawyer. If I think of that now I do not think that I would manage. Interviewer: Why do you think that?

Reza: I think it involves too much studying.

Rostam: And language. You need to speak perfect Swedish in order to be a lawyer. Reza: And I do not!

Interviewer: Do you think that your Swedish will hinder you in your future careers?

Reza: Yes! I think it will be difficult to talk perfect Swedish. And that is what is needed.

Interviewer: But you have only been here for a short time and your Swedish has developed a lot during this time. Now that you will be in upper secondary education for a while and then in university, don't you think that your Swedish will get good enough during this time?

Reza: No! You make progress but... [unfinished sentence].

Rostam: No! You might learn but it will take such a long time. Longer than those years. 
In contrast, Roya and Roshanek thought that although their language deficits might prolong their study time it would not be a complete barrier to achieving their goals. Moreover, the two boys said that it would be impossible for them to get the jobs of their dreams because of being foreigners and immigrants, but the girls did not mention the risk of being stigmatised as immigrants as a major barrier in their careers.

The students admitted to experiencing some elements of what might be called discrimination (Pollak 2008) or everyday racism (Gillborn 2006). Earlier research (Gillborn et al. 2012) has shown that students with foreign backgrounds are often subject to low expectations on the part of teachers, such as implications that they should be satisfied with just a pass grade. This pattern is to some extent evident in our study: the students said they were treated differently, for instance by teachers having lower expectations of them than of other students. At the same time their background was very rarely taken into account in the teachers' practice or the materials used, even though the interviewed students asked for what could be described as a more intercultural approach (cf. Rosvall and Öhrn 2014; Virta 2016). Occasionally an immigrant student would be left without further help with the comment "You cannot expect more", implying "she/he is good but the language is a problem", rather than the teacher making the effort to explain matters in other ways. The following field note from a mathematics class exemplifies this problem:

The teacher steps over to me at the back of the classroom after helping Roya. She explains that she sometimes directs immigrant students to tasks that don't require reading information since the language is too difficult for them. (field note)

This lack of help and low expectations may make it more difficult for immigrant students to achieve their career goals. 
The high ambitions of our interviewees fit a broader pattern, found in both Sweden (Jonsson and Rudolphi 2011) and other parts of Europe (Salikutluk 2016), that immigrants have relatively high aspirations compared to their native counterparts. Our research participants do not conform to norms amongst Swedish rural youth, who more commonly choose a vocational upper secondary programme. Nevertheless, immigrants are generally under-represented at university level. Of the cohort born in 1983, by the age of 25 only $37 \%$ of those with an immigrant background had continued to university, compared to $45 \%$ of the same age group with a Swedish background. However, those of a Persian background are exceptions, for example, $60 \%$ of those of Iranian background within this age cohort had continued to university (Swedish National Agency for Higher Education, 2010). Thus, our research participants do conform to the dominant pattern amongst other people of similar descent living in Sweden.

Both immigrants and native Swedes are known to regard being a physician as a valued profession, so it is not surprising that the girls among our participants aspired to become physicians, given their high ambitions. However, employers, colleagues and customers in the labour market generally devalue the resources (such as skills and social capital) of immigrants, even those who become physicians, particularly women physicians (Salmonsson and Mella 2013). Immigrant physicians interviewed by the cited authors described their skills and social capital being devalued in interactions with colleagues, career advancement and patients' responses to descriptions they presented or treatments they prescribed. They ascribed some of this devaluation to negative associations with characteristics such as their accent, and the colour of their hair and eyes. Nevertheless, being a physician seemed more valued, or less devalued, than many other professions, for example those that do not require certified expertise. The girls' aims to become physicians can partly be understood through reference to critical theory 
(Gillborn 2006): they seemed aware of their habitus and aiming to be a physician was a vocational goal within their horizon of action (Hodkinson and Sparkes 1997).

\section{Considering the local and the global}

As discussed above, our participants' horizons of action seemed to vary by gender with, for instance, the girls feeling less limited than the boys by their imperfect command of the Swedish language. There were also differences in how they discussed the marginalisation of immigrants; the boys raised this issue, but not the girls:

Interviewer: How would you describe what it's like to live here?

Rostam: It is calm and quiet here, that is the best.

Interviewer: You think that the best thing is that it is calm and quiet?

Rostam: Yes!

Interviewer: Can you describe what you mean by calm and quiet?

Rostam: Err, there are not as many fights and conflicts [with immigrants] as there are in the larger cities. You know, like police and criminals and such. But here, err, there is none of that, so to speak.

Interviewer: When you say calm and quiet I associate that with the closeness to the forests and nature, but you are thinking about there being fewer conflicts. Is that right?

Rostam: Yes!

Interviewer: What do you think about this?

Reza: I would rather live here than in the south. In the south there are more people and where there are more people it easily leads to more conflicts. I think it is better here. And the closeness to the forest is good. You can go out and run. I do that sometimes.

For the boys, the place itself did not seem very important. They most appreciated the absence of conflicts between immigrants and groups with violent attitudes towards immigrants and the police. In the open spaces of River School it was usually readily 
apparent that groups of recent immigrant students stuck together and rarely played with students born in Sweden. When Rostam and Reza were asked about this division they replied that it was $\mathrm{OK}$, as long as there were few conflicts and, anyway, there was little they could do about it. They added that they wanted to stay in this small town because, from what they had heard, there was much worse conflict and violence related to immigrant issues in large cities. Comments such as 'It is calm' can be interpreted as expressing feelings of security, contrasting with their sense that urban areas are insecure (cf. Cohen et al. 2011). Rostam and Reza specifically mentioned Stockholm in this context, but experiences of stigmatisation are well documented in research across Europe (cf. Massey 1994 p. 169). Interestingly, in other interviews with children of Swedish background in River Town some of them referred to the presence of violence and threats between different groups locally. Nevertheless, to Reza and Rostam it seemed a safer place than larger urban areas.

In addition, they thought of the municipality as a safe employer:

Rostam: I will go to upper secondary school, then university. Interviewer: Do you have any plans for your university studies?

Rostam: No!

Reza: I have no idea!

Rostam: It will probably be social science. I want to work doing something in the municipal services. The municipality is better. There is not as much harassment and so on.

Reza: I will do the same. I have thought of going to study at university in Gothenburg but I do not know anyone there. Then I will move back here. I like it here.

These comments suggest that concerns about conflict have shaped the boys' career aspirations in several ways. Firstly, they favour staying in the local town since they think of it as less threatening in terms of risks of everyday racism or open conflict. 
Secondly, they gravitate towards the municipality as a preferred employer since they think of it as offering workplaces where there is relatively little harassment of people of foreign origin.

The boys we interviewed were integrated, to some degree, into groups in the local society. Notably, they practiced at least one team sport, which Rostam, Reza and the boys of Swedish descent interviewed in the broader project mentioned above said provided important opportunities to meet other people. In contrast, Roshini and Roya engaged in individual (rather than team) sports, and Roshanek did none.

Involvement in local sports groups might partly explain why the boys seemed to feel more connected to the place than the girls did. It was also apparent during classroom observation that the immigrant boys tended to interact more with other students than the immigrant girls, who tended to keep more to themselves. Similarly, immigrant boys appeared to be more often invited by other students (especially girls) to participate in activities than the immigrant girls were. The general tendency for girls to promote integration in the classroom more than boys may seem paradoxical since, as mentioned above, the boys of both immigrant and Swedish descent mentioned that participation in sports favoured integration (so the patterns in the classroom and sports fields differed). The tendency for boys to be invited to participate in school activities more often than girls was particularly apparent during a dance lesson in a sports class in River School, where Swedish-born girls invited immigrant boys to dance, while Swedish born boys appeared to avoid inviting the immigrant girls:

The teacher tells the students to divide into one group of girls and one of boys. He then tells the boys to invite the girl closest to them to dance. The boys adjust their position but all the girls get invited. The immigrant girls are invited last. [...] Now it is the girls turn to invite the boys. Rebecca and Rita actively go over to Reza and 
Rostam and invite them to dance. [...] Now it is the boys' turn to invite the girls again. Roger is engaged in talking with a friend and suddenly only him and Roshanek are left. Roger goes over to the teacher and tells him that he does not want to dance with Roshanek. Roshanek seems embarrassed and looks at the floor with her shoulders drooping.

Differences in levels of interaction with others, both within and outside school, might explain why the immigrant boys in River School seemed more rooted than the girls, and wanted to develop their careers with a view to staying in River Town.

Neither the observations nor comments recorded during the interviews in this study can explain why the girls invited the immigrant boys to participate in school activities more commonly than the boys. However, during the student interviews boys made comments that could be interpreted as xenophobic, either explicitly or implicitly, but none of the girls made such statements. This can potentially be explained from a gender order perspective, regarding racism as one dimension of social domination that is closely connected to constructions of hegemonic masculinities (Connell 1987). Moreover, it may at least partially explain the classroom observations that only the immigrant boys were invited to participate in the dance class, not the immigrant girls, as the girls of Swedish descent may have felt closer in status to the immigrant boys than the boys of Swedish descent felt to the immigrant girls.

According to the Swedish 'Index of attitudes towards diversity' (Ahmadi, Palm and Ahmadi 2016), 84 percent of a set of interviewees selected to be representative of the Swedish population thought that human rights conflict with Islamic values, but just 16 per cent saw a similar conflict with Christian values. Furthermore, negative attitudes towards individuals from the Middle East were most prominent. For example, 38 percent of the interviewees did not think that individuals from the Middle East could be integrated into Swedish society, compared to 26 percent for individuals of African 
origin. In addition, as in studies elsewhere, for example the USA (Hall 2016), participants in the cited Swedish study considered men to pose a larger threat than women: 43 and 21 per cent, respectively, said that Middle eastern men and women could be a threat to Swedish culture (Ahmadi et al. 2016). Kamali (2015) connects the global and the local by using the concepts of Bourdieu and Foucault. He argues that Muslims are used in contemporary political discourse to serve as 'dangerous' populations and being used as a cover for imposing an 'us' and 'them' division that creates excluded populations. Kamali uses the term 'glocal' when arguing that the politics of the global is used by those who have sufficient cultural capital in the local setting to define the 'included' and the 'excluded'. The differences in negative attitudes with respect to gender and understanding of the 'glocal' might help us understand why the boys seemed to adopt strategies to avoid strong stigmatisation more than the girls, manifested in a stronger commitment to stay in the local area.

While the boys emphasised their sports practice the girls talked about family activities:

\footnotetext{
Interviewer: It is clearly visible in class that you are good friends. Do you also meet after school?

Roshini: Yes! At family parties and at the public bath. We go there on Sundays. Interviewer: What do you do on week nights then?

Roya: I'm with the family. The family are the most important people.

Roshini: Yes! To me too! My family and siblings.
}

Although the girls did go out into public arenas they tended to do this together with their family, and did not appear to develop other ongoing social relations equivalent to those that the boys were developing through their sports clubs, regularly practicing and spending time with the same individuals. Roya and Roshini went to the public bath together with other immigrant families who had fewer obvious local connections or 
attachments than the Swedish boys (born and raised in River Town) that Reza and Rostam met through football or hockey presumably had.

Life is more difficult for individuals with limited social networks within the local context in many ways. For instance, most Swedish schools arrange a few weeks of workplace training for students, usually during the final years of compulsory education. However, each municipality organises this themselves, so arrangements vary between municipalities and schools. Some municipalities do not offer it at all. River School offered workplace training for two weeks towards the end of ninth grade. Students were required to make contact with the workplaces by themselves, but none of the immigrant students had found a workplace training placement. Some had not even tried to do so:

Interviewer: You just had your workplace training didn't you?

Roshanek: I did not have any workplace training. I could not find a place to go to.

All the other ninth graders had their workplace training.

Interviewer: So, what did you do?

Roshanek: I practiced some of my subjects, such as Art and so on.

Interviewer: What do you know about the companies and employers here in River Town? Would you like to work here in the future?

Roshanek: Not much!

There was no difference between the boys and girls in this respect: in all cases the opportunity for workplace learning, which could have provided a chance to develop their knowledge of the local labour market, was missed.

In the interviews there were several indications that the girls felt less connection than the boys to the rest of local society. This was not necessarily explicit but was implied through an absence of any mention in their comments on building a career in the local area and more emphasis on their career development taking them to larger Swedish cities or overseas: 
Interviewer: When you finish your education as a physician do you imagine yourself living in this town in the future?

Roshini: No! I would go to a larger city for my studies and then probably stay there. I might work here as well. But it would not be so easy to combine. You know, I would like to work half time here and half time in my country because I am much more needed there. You know my parents are from Afghanistan but they escaped from there to Pakistan and I was born there. Then we moved to Iran and we lived there for 10 years before we moved to Sweden. My real home country is Afghanistan and there they need a lot of physicians. Therefore, I want to be a physician.

Even though Roshini has never been to Afghanistan she refers to it as her home country and feels that it is important to use her skills there because the people of Afghanistan are in greater need (cf. Salomone 2008). This example reinforces existing arguments (Lundqvist and Olsson, 2012) that study and career advisers should take into account both the transnational and the local when advising young people (cf. Neault 2005) and be mindful of the intercultural interplay between understandings of citizenship and career development (cf. Coulby 2006; Gorski 2008; Perry and Southwell 2011).

\section{Conclusions}

Previous studies have analysed patterns of migrant employment and considered effects of factors such as former nationality, marital status and place (Bevelander and Pendakur 2012; Jonsson and Rudolphi 2011). Most of these studies, both in Sweden and elsewhere, have focused on urban or suburban youth (Hertzberg and Sundelin 2014; Lundqvist and Olsson 2012; Runfors 2016). Runfors (2016) notes the similarities between Swedish and other western studies in observing how whiteness is the dominant cultural norm against which the racial 'other' is shaped, and showing how this affects the conditions for individuals' career development. However, she also notes some important differences. For instance, in the USA low status positions are associated with 
being a person of colour while in Sweden such roles are associated with being an immigrant, distinguished by a foreign accent and both hair and eye colour. This study supports this observation in that the two boys discussed their Swedish language limitations as a barrier to their career plans. In addition, it seems the 'skin-tone hierarchy' referred to in the US context (Keith and Monroe 2016) is weaker in Sweden and discrimination is based more on negative attitudes related to a religion (Islam) associated with a particular region, the Middle East (cf. Ahmadi et al. 2016).

Our analysis of interviews with young immigrants in a rural town in Sweden has generated some interesting insights. Firstly, the girls rather than the boys aspire to the higher paid roles, whilst the boys' career choices seem to be more influenced by their experiences of the social context. In this respect the girls were somewhat more optimistic (Bimrose 2001). More broadly, in terms of gender and immigrant background, our findings support earlier studies in showing that both boys and girls favour career paths similar to the general patterns for immigrant youth of Persian descent in Sweden. What this study adds is intercultural knowledge of how living in a rural place seems to intersect with the influences of gender and immigrant background. Specifically, the boys were more concerned about the perceived stigma of being immigrants to Sweden, and this affected their horizon of action (Hodkinson and Sparkes 1997). The boys' assumptions about the labour market being somewhat more difficult if you have an immigrant background are corroborated by previous findings that members of minority ethnic groups tend to have lower than average earnings (Carlsson and Rooth 2016) and that people of foreign descent can find it more difficult to get to job interviews (Midtbøen 2016). The boys participating in this study thought of the rural town as a place where it would be relatively easy to make informal contacts that may help them get a job, and that their participation in team sports had been a useful 
platform for building such contacts. Accordingly, personal relationships have previously been established as important factors in career development (Connell 1987; Hodkinson and Sparkes 1997).

Massey (1994) has taken the analysis of social relationships further, concluding that:

Different social groups have distinct relationships to differentiated mobility: some people are more in charge of it than others; some initiate flows and movement, others don't; some are more on the receiving-end of it than others; some are effectively imprisoned by it. (p.149)

This kind of 'differentiated mobility' is evident in our findings, as differences have emerged in degree to which the research participants felt able to 'initiate flows and movements' (see also Salomone 2008, this journal). The girls felt able to envisage careers as physicians, which would take them beyond the local area despite the likelihood of facing discrimination once they were in these roles (Salmonsson and Mella 2013).

The boys, meanwhile, were pursuing more local ambitions, based on their perceptions of how immigrants are treated both where they live and in larger urban areas. Although there is nothing inherently negative about the boys' intention to choose careers close to their current home, it is important to acknowledge how their aspirations have been constrained by the power relations they are embedded in. Their focus on service sector jobs in the local municipality can be seen as a response to 'interactions with the outside' (Massey 1994) in which expectations of facing everyday racism (Gillborn 2006) made other urban areas seem more difficult places to thrive than their rural home town. Their focus on service sector jobs provided by a 'safe employer', the local municipality, can be seen as a response to 'interactions with the outside' (Massey 1994) in which expectations of facing everyday racism (Gillborn 2006) made other 
urban areas seem more difficult places to thrive than their rural home town. Our interviewees' ambitions are also consistent with a strong orientation among immigrants nationally towards the public sector in university studies (Swedish statistics 2016d).

\section{Implications for practice}

Given that racial and gender socialization frequently starts at an early age, career counsellors must be aware that young people enter school settings with racially conscious mindsets that are gender-specific (Hall 2016). Hence, immigrant boys and girls (and their career choices) will likely be affected in different ways by 'colourism' and other forms of discrimination, such as the anti-Islam bias in Sweden noted above. Legally and morally, career counsellors cannot accept prejudice against immigrants. However, they must reflect on effective ways to address immigrant youths' notion (clearly expressed by the boys we interviewed) that they will be constrained by prejudice associated with their background, regardless of personal effort.

Although this study is based on a small sample it provides intercultural insights that highlight the importance of career counsellors taking into account the notion of place when talking with immigrant youth about their careers. Both the local and global contexts affected the horizons of action of our research participants, and these factors intersected with gender in different ways. Roshini's dream of working across two geographically disparate places highlights the importance of student and career counsellors knowing something about work in other countries, and acknowledging not only local but also global environments as potential fields for employment.

Hertzberg and Sundelin (2014) observed that dealing with a client's immigrant background can be problematic for career counsellors. Failing to engage with it can be detrimental to establishing trust and make the client feel the counsellor does not 
understand the particular challenges s/he faces, while over-emphasising it can come across as stigmatising. Counsellors must, then, find a balance between these risks.

Hall (2016) adds that professionals must be aware that they themselves and the individuals they meet are inevitably influenced by the variation in complexion within racial groups, which may depend on factors such as gender and experience of discrimination. To counter this (and other forms of bias), partnerships with peers working in suburban areas who have a longer history of counselling youth of immigrant background may enhance the professional development of career counsellors in rural areas. Moreover, such partnerships may be helpful for those working in urban areas when counselling those seeking employment in rural areas or potentially facing forms of discrimination that we do not recognize in ourselves because they are so deeply normalized.

Whilst these interviews were not directly about counselling practice the research participants' immigrant backgrounds clearly affected their career plans in terms of where they intended to work. Power relations around ethnicity and gender were also significant. As proposed by Gorski (2008), attention to socio-political contexts and an intercultural approach that transcends cultural awareness, thereby helping individuals to move beyond their constraints, challenge their preconceptions and broaden their aspirations, are core elements of effective career counselling (Bimrose and McNair 2011; Pollak 2008). The ability to engage with these aspects of young immigrants' expectations is particularly crucial, because the challenges they face are particularly severe. 


\section{References}

Ahmadi, F., I. Palm and N. Amadi 2016. Mångfaldsbarometern [Index of attitudes towards diversity]. Gävle: University of Gävle.

Bevelander, P., and R. Pendakur 2012. "Citizenship, Co-ethnic Populations, and Employment Probabilities of Immigrants in Sweden." Journal of International Migration and Integration 13 (2): 203-222. doi:10.1007/s12134-011-0212-6.

Bimrose, J. 2001. "Girls and women: Challenges for careers guidance practice." British Journal of Guidance \& Counselling 29 (1): 79-94. doi:10.1080/03069880020019392.

Bimrose, J., and S. McNair. 2011. "Career support for migrants: Transformation or adaptation?" Journal of Vocational Behavior 78 (3): 325-333. doi:http://dx.doi.org/10.1016/j.jvb.2011.03.012.

Blumer, H. 1956. "Sociological analysis and the 'variable'." American sociological review 21 (6): 683-690. URL: http://www.jstor.org/stable/2088418.

Carlsson, M., and D.-O. Rooth. 2016. "Employer Attitudes, the Marginal Employer, and the Ethnic Wage Gap.” ILR Review 69 (1): 227-252. doi:10.1177/0019793915601630.

Cho, J., and A. Trent. 2006. "Validity in qualitative research revisited." Qualitative Research 6 (3): 319-340. doi:10.1177/1468794106065006.

Cloke, P. 2006. "Conceptualizing rurality." In The handbook of rural studies edited by P. Cloke, T. Marsden and P. Mooney, 18-28. London: SAGE Publications Ltd.

Cohen, L., J., Arnold and M. O'Neill. 2011. "Migration: Vocational perspectives on a complex and diverse transition." Journal of Vocational Behavior 78 (3): 321324. doi:http://dx.doi.org/10.1016/j.jvb.2011.03.011.

Collantes, F., V. Pinilla, L. Sáez and J. Silvestre. 2014. "Reducing Depopulation in Rural Spain: The Impact of Immigration.” Population, Space and Place 20 (7): 606-621. doi:10.1002/psp.1797.

Colley, H. 2003. "Engagement mentoring for socially excluded youth: Problematising an 'holistic' approach to creating employability through the transformation of habitus.” British Journal of Guidance \& Counselling 31 (1): 77-99. doi:10.1080/0306988031000086189.

Connell, R., W. 1987. Gender and Power. Stanford: Stanford university press. 
Corbett, M. 2005. "Rural education and out-migration: The case of a coastal community." Canadian journal of education 28 (1-2): 52-72. URL: http://www.jstor.org/stable/1602153.

Coulby, D. 2006. "Intercultural education: theory and practice.” Intercultural Education 17 (3): 245-257. doi:10.1080/14675980600840274.

Denzin, N. K. 1989. The research act: a theoretical introduction to sociological methods (3 ed.). Englewood cliffs: Prentice Hall.

Doolan, K., N. Lukić and N. Buković. 2016. "The Embodiment of Class in the Croatian VET School System.” European Journal of Education 51 (3): 345-359. doi:10.1111/ejed.12183.

Gillborn, D. 2006. "Critical Race Theory and Education: Racism and anti-racism in educational theory and praxis." Discourse: studies in the cultural politics of education 27 (1): 11-32. doi:10.1080/01596300500510229.

Gillborn, D., N. Rollock, C. Vincent and S. Ball. 2012. "'You got a pass, so what more do you want?': race, class and gender intersections in the educational experiences of the Black middle class." Race Ethnicity and Education 15 (1): 121-139. doi:10.1080/13613324.2012.638869.

Gorski, P. 2008. “Good intentions are not enough: a decolonizing intercultural education.” Intercultural Education 19 (6): 515-525. doi:10.1080/14675980802568319.

Hall, R. 2016. "The Bleaching Syndrome: The Role of Educational Intervention.” Theory into Practice 55 (1): 62-68. doi:10.1080/00405841.2016.1116877

Hertzberg, F., and Å. Sundelin. 2014. "Counseling between recognition, justice and difference.” International Journal for Educational and Vocational Guidance, 14 (1): 89-102. doi:10.1007/s10775-013-9261-z.

Hjelmér, C., and P.- $\AA$. Rosvall. 2016. “Does social justice count? 'Lived democracy' in mathematics classes in diverse Swedish upper secondary programmes.” Journal of Curriculum Studies. Advance online publication. doi:10.1080/00220272.2016.1138326.

Hodkinson, P., and A. Sparkes.1997. "Careership: a sociological theory of career decision making." British Journal of Sociology of Education 18 (1): 29-44. doi:10.1080/0142569970180102. 
Holm, A.-S. 2010. "Gender Patterns and Student Agency: Secondary School Students' Perceptions over Time.” European Educational Research Journal 9 (2): 257 268. doi:10.2304/eerj.2010.9.2.257

Jeffrey, B., and G. Troman. 2004. “Time for ethnography.” British Educational Research Journal 30 (4): 535-548. doi:10.1080/0141192042000237220.

Jonsson, J., and F. Rudolphi. 2011. "Weak Performance—Strong Determination: School Achievement and Educational Choice among Children of Immigrants in Sweden.” European Sociological Review 27 (4): 487-508. doi:10.1093/esr/jcq021

Kamali, M. 2015. War, violence and social justice. London: Ashgate.

Keith, V., and C. Monroe. 2016. Histories of Colorism and Implications for Education. Theory into Practice 55 (1): 4-10. doi:10.1080/00405841.2016.1116847

Lindgren, J. 2010. "Diaspora biographies balancing ideology and utopia: On future orientations of immigrant youth in a segregated Sweden." Young 18 (2): 177195. doi:10.1177/110330881001800204

Lundahl, L. 2011. "Swedish upper secondary education: Policy and organisational context." In Young people's influence and democratic education: Ethnographic studies in upper secondary schools, edited by E. Öhrn, L. Lundahl and D. Beach, 13-27. London: Tufnell press.

Lundqvist, C., and E. Olsson, E. 2012. "Beyond a Swedish horizon - Young migrants in Sweden and their transnational prospects." Nordic Journal of Migration Research 2 (2): 124-132. doi:10.2478/v10202-011-0034-9.

Maiztegui-Oñate, C., and R. Santibáñez-Gruber. 2008. "Immigrant access to education: a comparative perspective.” Intercultural Education 19 (5): 369-371. doi:10.1080/14675980802531408.

Massey, D. 1994. Space, place and gender. Cambridge: Polity press.

Midtbøen, A. 2016. "Discrimination of the Second Generation: Evidence from a Field Experiment in Norway.” Journal of International Migration and Integration 17 (1): 253-272. doi:10.1007/s12134-014-0406-9.

Neault, R. 2005. "Managing Global Careers: Challenges for the 21st Century." International Journal for Educational and Vocational Guidance 5 (2): 149-161. doi:10.1007/s10775-005-8796-z.

Nilsson, A. 2004. Demographic Reports 2004:5 Immigration and emigration in the postwar period. Stockholm: Statistics Sweden. 
Nylund, M., and P.-Å. Rosvall. 2016. “A curriculum tailored for workers? Knowledge organization and possible transitions in Swedish VET." Journal of Curriculum Studies 48 (5): 692-710. doi:10.1080/00220272.2016.1138325.

Perry, L., and L. Southwell. 2011. "Developing intercultural understanding and skills: models and approaches." Intercultural Education 22 (6): 453-466. doi:10.1080/14675986.2011.644948.

Pollak, A. 2008. "Discrimination and good practice activities in education: trends and developments in the 27 EU Member States." Intercultural Education 19 (5): 395-406. doi:10.1080/14675980802531580.

Rao, N., and M. Hossain. 2012. “'I Want to Be Respected': Migration, Mobility, and the Construction of Alternate Educational Discourses in Rural Bangladesh.” Anthropology \& Education Quarterly 43 (4): 415-428. doi:10.1111/j.15481492.2012.01194.x.

Rosvall, P.- $\AA$. 2015. “'Lad' research, the reproduction of stereotypes? Ethnographic dilemmas when researching boys from working-class backgrounds." Ethnography and Education 10 (2): 215-229. doi:10.1080/17457823.2015.1016054

Rosvall, P.-Å., and E. Öhrn. 2014. “Teachers' silences about racist attitudes and students' desires to address these attitudes." Intercultural Education 25 (5): 337 348. doi:10.1080/14675986.2014.967972.

Runfors, A. 2016. "What an ethnic lens can conceal: the emergence of a shared racialised identity position among young descendants of migrants in Sweden." Journal of Ethnic and Migration Studies 42 (11): 1846-1863. doi:10.1080/1369183x.2016.1153414.

Salikutluk, Z. 2016. "Why Do Immigrant Students Aim High? Explaining the Aspiration-Achievement Paradox of Immigrants in Germany.” European Sociological Review 32 (5): 581-592. doi:10.1093/esr/jcw004.

Salmonsson, L., and O. Mella. 2013. "Cultural demands on skilled immigrants, a devaluation of human capital. The case of immigrant physicians in Sweden." Nordic Journal of Migration Research 3 (1): 3-9. doi:http://dx.doi.org/10.2478/v10202-012-0008-6.

Salomone, R. 2008. "Transnational schooling and the new immigrants: developing dual identities in the United States." Intercultural Education 19 (5): 383-393. doi:10.1080/14675980802531572. 
Statistics Sweden 2008. Demographic reports 2008:4 Immigrants' migration patterns. Stockholm: Statistics Sweden.

Statistics Sweden 2015. Population statistics: Population increase is spread across the entire country. Örebro: Statistics Sweden.

Statistics Sweden 2016a. From Finland to Afghanistan - immigration and emigration since 1970 for persons born in different countries. Stockholm: Statistics Sweden.

Statistics Sweden 2016b. Integration - establishment of foreign born persons in working life and society. Stockholm: Statistics Sweden.

Statistics Sweden 2016c. Integration - internal migration among refugees in Sweden. Stockholm: Statistics Sweden.

Statistics Sweden 2016d. Swedish and foreign background among students and doctoral students in higher education 2014/15. Stockholm: Statistics Sweden.

Swedish Association of Local Authorities and Regions 2010. Kommungruppsindelning 2011 [Classification of Swedish municipalities, 2011]. Stockholm: SKL.

Swedish National Agency For Higher Education 2010 Foreign background among students in higher education 2008/09. Stockholm.

The National Board of Health and Welfare 2013. Labour Supply in Sweden: Midwives, Nurses, Physicians, Dental Hygienists and Dentists 2013. Stockholm.

Unjore, S. 2014. "Excitement or anxiety? A case study of Indian postgraduate sojourners at University of Nottingham." British Journal of Guidance \& Counselling 42 (5): 557-567. doi:10.1080/03069885.2014.933174.

Walford, G., ed. 2008. How to do educational ethnography. London: Tufnell press.

Virta, A. 2016. "Whose history should be dealt with in a pluricultural context immigrant adolescents' approach.” Intercultural Education. Advance online publication. doi:10.1080/14675986.2016.1216950 